\title{
EXPERIMENTAL STUDY AND FINITE ELEMENT MODELLING OF PUSH-OUT TESTS ON A NEW SHEAR CONNECTOR OF I-SHAPE
}

\author{
Messaoud Titoum $^{1, *}$, Aida Mazoz ${ }^{1}$, Abdelkader Benanane $^{2}$ and Djamel Ouinas ${ }^{3}$ \\ ${ }^{1}$ Laboratory of Materials and Mechanics of Structures, University of M'sila 28000, Algeria \\ ${ }^{2}$ Laboratory of Materials and Processes of Construction, University of Mostaganem 27000, Algeria \\ ${ }^{3}$ Laboratory of numerical and experimental modelling of the mechanical phenomena, University of Mostaganem \\ 27000, Algeria \\ *(Corresponding author: E-mail: titoum65@yahoo.fr)
}

Received: 2 February 2016; Revised: 24 March 2016; Accepted: 26 March 2016

\begin{abstract}
In this paper, we present the results of experimental study and finite element modeling of the push-out tests on a new shear connector of I-shape. 24 push-out specimens with I-shape shear connectors were tested under a static loading in the Laboratory of Materials and Mechanics of Structures - LMMS at the University of M'sila, Algeria. The test specimens were designed to study the effect of the following parameters on the ultimate load capacity: the height of I-shape connector, the length of I-shape connector, the compressive strength of concrete and the number of transverse reinforcing bars. The load capacity, the ductility and the modes of failure were presented and discussed. Furthermore, a finite element modelling of the push-out tests was carried out using ANSYS software to investigate the stress distribution pattern in the area of the I-shape connector. Moreover, the finite element model was also used to simulate another type of shear connector, called channel connector in order to compare its behaviour with that of the I-shape connector. From this comparison, we suggested an equation for the prediction of the ultimate load capacity of I-shape shear connectors.
\end{abstract}

Keywords: Steel-concrete connection, I-shape shear connector, Push-out tests, F.E.M.

DOI:10.18057/IJASC.2016.12.4.7

\section{INTRODUCTION}

The shear connectors are commonly used to ensure composite action in a steel-concrete composite beam. Their main function is to resist longitudinal shear forces at the steel-concrete interface, and to prevent vertical separation between the concrete slab and the supporting steel beam. Many types of shear connectors have been developed and used in the past. The most widely used shear connector in practice is the welded stud (Figure 1(a)) with a suitable head that contributes to the shear transfer and prevents the uplift. Nevertheless, due to the small load carrying capacity of stud connectors and also due to the fatigue problems caused by live loads on composite bridges, some other alternative shear connectors are proposed such as the angle connector with anti-uplift bar (Figure 1(b)) and the channel connector (Figure 1(c)) which are frequently used in Algeria and in some other countries.

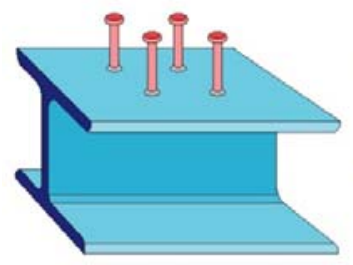

(a ) : Stud connector

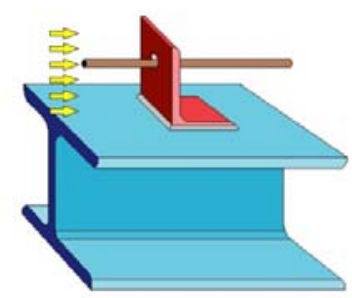

(b) : Angle connector

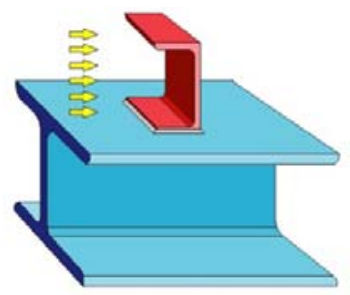

(c) : Channel connector

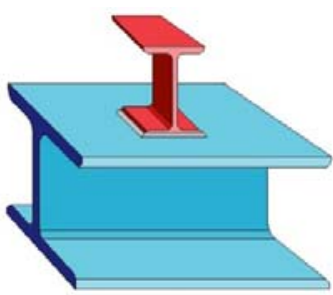

(d) I-shape connector

Figure 1. Types of Shear Connectors 
The economic considerations continue to motivate the development of new systems to ensure the load transfer between steel and concrete components in composite structures. Recently, several authors have proposed new types of shear connectors, such as Y-type perfobond rib connector [1], J-hook connector [2], Bolted connector [3], Rubber-sleeved stud [4], and V-shaped angle connector [5]. In this context, a new shear connector, called I-shape connector is proposed. As shown in Figure 1(d), the shape of this connector is appropriate to resist shear forces and prevent vertical separation between the steel beam and the concrete slab. In addition, angle and channel connectors [6] are limited to shear transfer in the recommended direction only, while the I-shape connector can resist and transfer shear in the two directions with same quantity, making it the more useful shear connector in composite beams subjected to seismic loading. Moreover, the facility of producing the I-shape connectors by their cutting from the ordinary laminated I profiles is another advantage. The welding task has the same characteristics as referred for angle and channel connectors.

A review of the literature indicates that any research work has been done to investigate the feasibility of using I-shape pieces as shear connectors. In this paper, we present the results of experimental study and finite element modelling of the push-out tests on a new shear connector of I-shape. 24 push-out specimens with I-shape shear connectors were tested under a static loading in the Laboratory of Materials and Mechanics of Structures - LMMS at the University of M'sila, Algeria. The load capacity, the ductility and the modes of failure were presented and discussed. The effect of the dimensions of I-shape connector, the effect of strength of concrete, and the effect of the number of transverse reinforcing bars have been discussed [7]. Furthermore, a finite element modelling of the push-out tests was carried out using ANSYS software [8] to investigate the stress distribution pattern in the area of the I-shape connector. Moreover, the finite element model was also used to simulate another type of shear connector, called channel connector (Figure 1(c)) in order to compare its behaviour with that of the I-shape connector. From this comparison, we suggested an equation for the prediction of the ultimate load capacity of the specific shear connector proposed in this research.

\section{EXPERIMENTAL PROGRAM}

The experimental program consisted of 24 push-out tests grouped in four series, each with three pairs. Each pair included two identical specimens. The test specimens were designed to study the effect of the following parameters on the ultimate load capacity: the height of I-shape connector, the length of I-shape connector, the compressive strength of concrete and the number of transverse reinforcing bars. Details of each push-out specimen are provided in Table1 with the dimensions of I-shape shear connector, the compressive strength of concrete slab and the number of transverse reinforcing bars. As illustration, Figure 2 shows the specimens of the series A.

Table 1. Summary of Push-out Test Specimens

\begin{tabular}{|c|c|c|c|c|c|c|c|}
\hline \multirow[t]{2}{*}{ Series } & \multirow[t]{2}{*}{ Specimen } & \multicolumn{3}{|c|}{ I-shape shear connector } & \multicolumn{2}{|c|}{ Concrete slab } & \multirow{2}{*}{$\begin{array}{c}\text { Test } \\
\text { parameter }\end{array}$} \\
\hline & & Profile & $\begin{array}{c}H_{I} \\
(\mathrm{~mm})\end{array}$ & $\begin{array}{c}L_{I} \\
(\mathrm{~mm})\end{array}$ & $\begin{array}{c}f_{c k} \\
\left(\mathrm{~N} / \mathrm{mm}^{2}\right)\end{array}$ & $\begin{array}{c}\text { Transverse } \\
\text { reinforcement }\end{array}$ & \\
\hline \multirow{6}{*}{ A } & A1-a & IEP80 & 80 & \multirow{6}{*}{60} & \multirow{6}{*}{20.11} & \multirow{6}{*}{$4 \varnothing 8$} & \multirow{6}{*}{$\begin{array}{l}\text { Height of } \\
\text { I-shape } \\
\text { connector }\end{array}$} \\
\hline & $\mathrm{A} 1-\mathrm{b}$ & IEF OU & 00 & & & & \\
\hline & A2-a & JEP100 & 100 & & & & \\
\hline & A2-b & ILI 100 & 100 & & & & \\
\hline & A3-a & JEP120 & 120 & & & & \\
\hline & A3-b & & & & & & \\
\hline \multirow{2}{*}{ B } & B1-a & \multirow{2}{*}{ IEP80 } & \multirow{2}{*}{80} & \multirow{2}{*}{40} & \multirow{2}{*}{26.52} & \multirow{2}{*}{$4 \varnothing 8$} & \\
\hline & B1-b & & & & & & \\
\hline
\end{tabular}




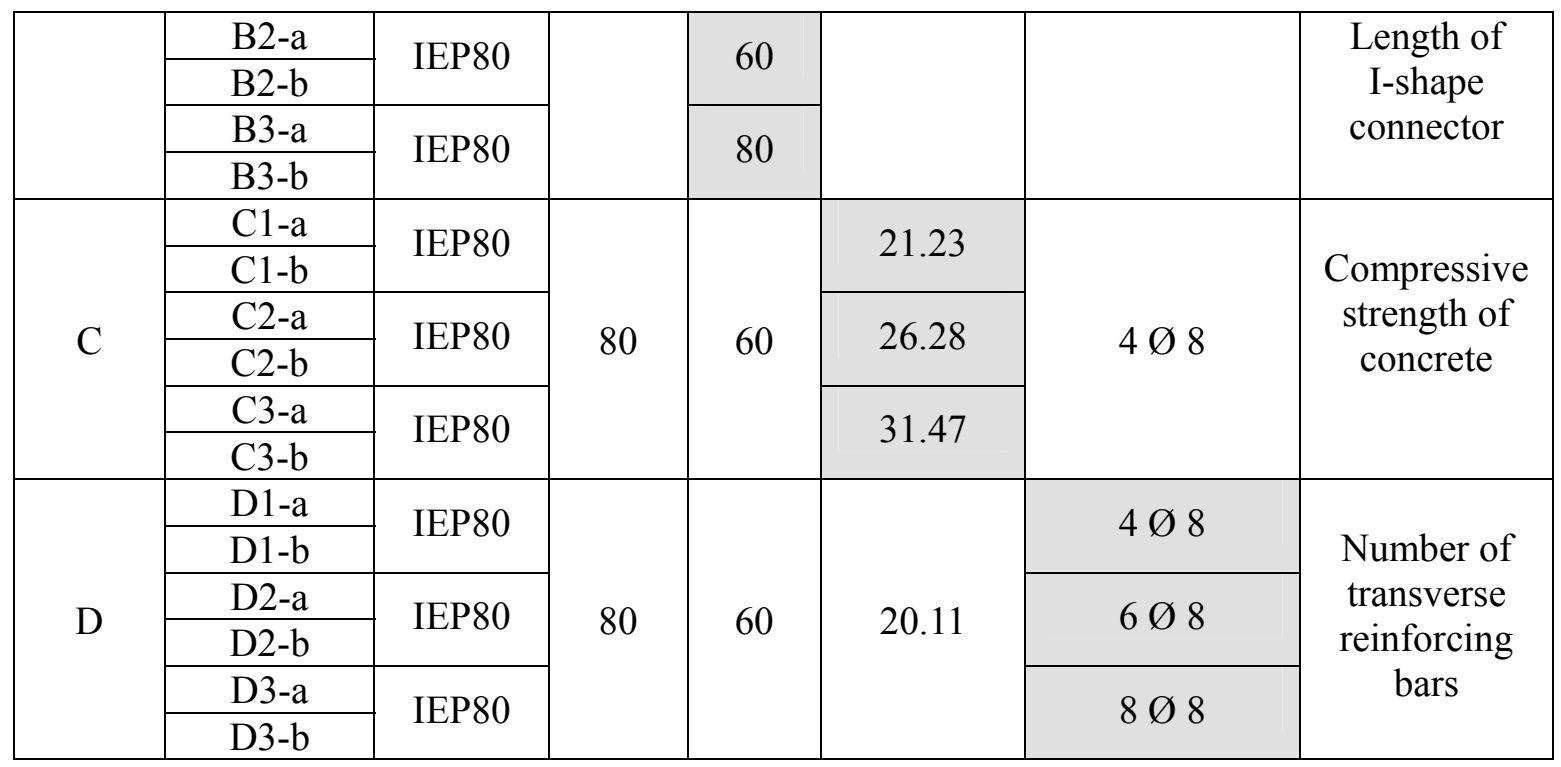

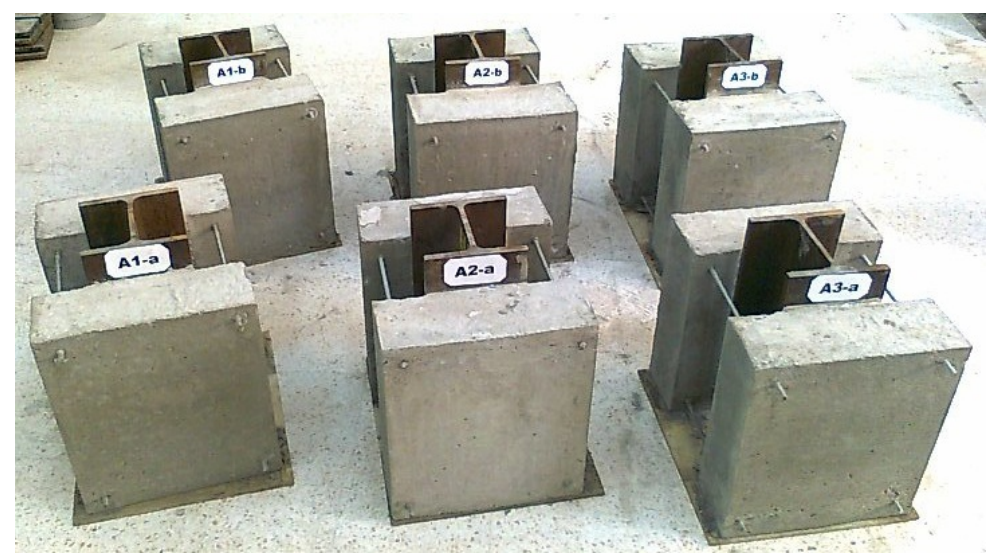

Figure 2. Push-out Specimens of the Series A

\subsection{Description of Push-out Specimens}

Due to some practical difficulties of the testing device, it was not possible to prepare the push-out specimens according to Eurocode 4 [9]. To simplify the experimental procedure, the authors have decided to follow the recommendations of British standards BS 5400-5 [10]. As shown in Figure 3, a push-out specimen consists of two small concrete slabs held in the vertical position, and attached to the flanges of a short HEB160 steel beam of $360 \mathrm{~mm}$ long, by means of welded I-shape shear connectors. The assembly was subjected to a vertical load which produced shear load along the interface between the concrete slab and the steel beam flange on both sides. A recess of $60 \mathrm{~mm}$ was provided between the bottom of the slab and the lower end of the steel beam to allow for slip during testing. The dimensions of concrete slabs were $360 \mathrm{~mm}$ long, $320 \mathrm{~mm}$ wide, and $120 \mathrm{~mm}$ thickness for each slab. For the specimens of series A, the thickness of the concrete slabs was 140 $\mathrm{mm}$ instead of $120 \mathrm{~mm}$. The distance between the web of I-shape connector and the bottom end of the concrete slab was kept constant at $210 \mathrm{~mm}$ for all specimens. These dimensions are similar to those used in other push-out tests with other types of shear connectors [11-15]. Most specimens were reinforced longitudinally and transversely with four $8 \mathrm{~mm}$ diameter bars positioned in two layers for each concrete slab, for some specimens in Series D, the number of longitudinal bars kept constant while the transverse bars were varied to six and eight bars for each concrete slab. The slabs of all push-out specimens were cast vertically, rather than horizontally, so that both slabs could be cast from the same batch of concrete to reduce the chance for variation in concrete 
strength from one slab to another. Each lift was thoroughly vibrated to eliminate air voids adjacent to the I-shape connectors. This form of casting has been successfully used by Veldanda \& Hosain [16], Studnicka et al [17], Medberry \& Shahrooz [18], Veríssimo [19], Vianna et al [20] and by Prakash et al [14]. Adoption of this procedure leads to a significant reduction of the time for execution of the test program, as well as of costs associates to the cut and the welding of the steel beams that would be necessary to execute the casting in horizontal position [21]. In addition, the casting in vertical position does not causes important modifications since the slabs have small dimensions. The chemical bond at the steel-concrete interface was eliminated by oiling the steel flanges before casting the slabs. The oiling of the steel flanges and the provision of the reinforcing bars before concrete pouring are shown in Figure 4.

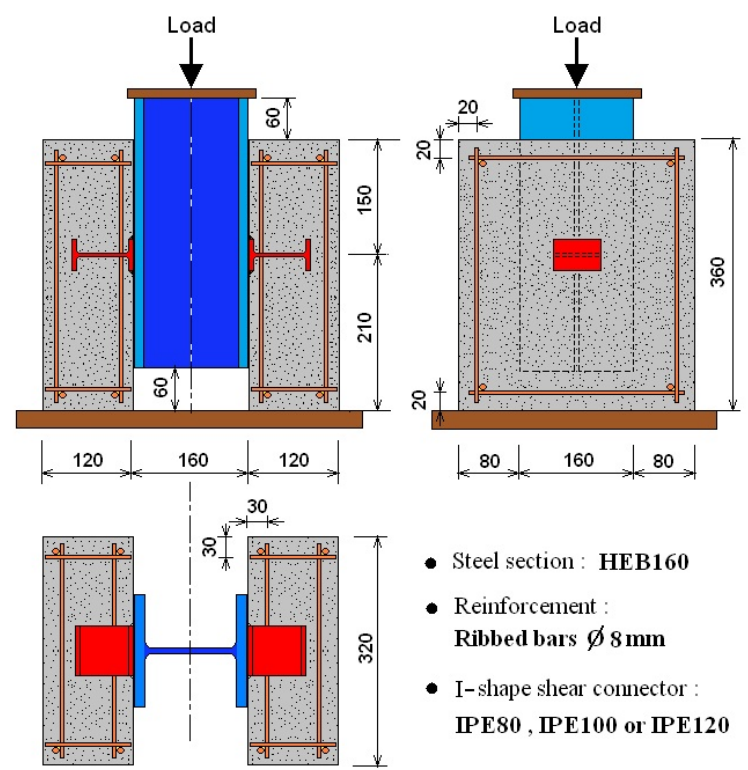

Figure 3. Push-out Specimen with I-shape Connector (Dimensions in $\mathrm{mm}$ )
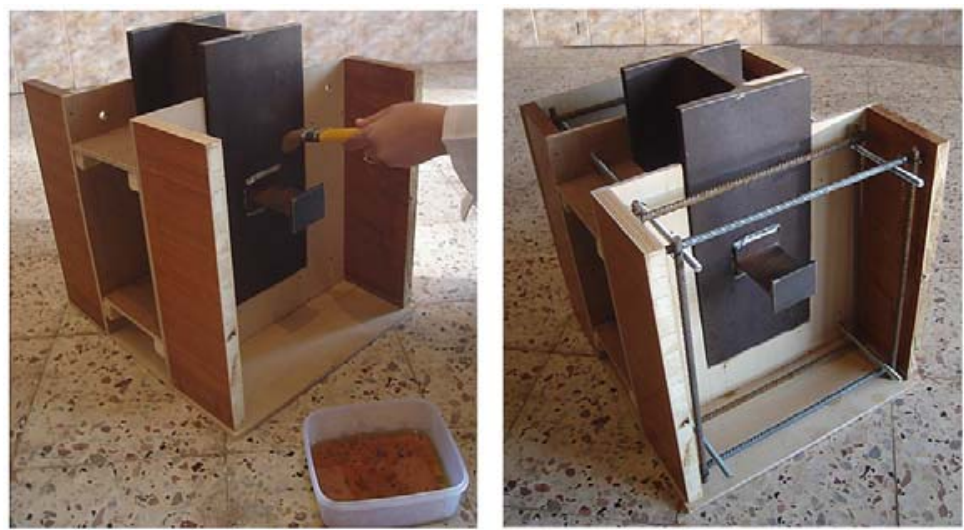

Figure 4. Oiling of the Steel Flanges and Provision of the Reinforcing Bars

\subsection{Material Properties}

After the concrete was cast for the push-out specimens, five concrete cylinders ( $160 \mathrm{~mm}$ diameter $\mathrm{x}$ $320 \mathrm{~mm}$ length) were prepared during each pouring. These concrete cylinders were tested for compressive strength on the same day of the push out tests. Table 2 shows the results of the compressive strength tests. The tensile strength and the modulus of elasticity of the concrete were calculated according to the procedure proposed by Eurocode 2 [22]. 
Table 2. Mechanical Properties of concrete material

\begin{tabular}{|c|c|c|c|c|}
\hline Specimens & $\begin{array}{c}\text { Strength } \\
\text { class of } \\
\text { concrete }\end{array}$ & $\begin{array}{c}\text { Average } \\
\text { compressive } \\
\text { strength, } f_{c k}(\mathrm{MPa})\end{array}$ & $\begin{array}{c}\text { Tensile } \\
\text { strength, } \\
f_{t}(\mathrm{MPa})\end{array}$ & $\begin{array}{c}\text { Modulus of } \\
\text { elasticity, } E_{c m} \\
(\mathrm{GPa})\end{array}$ \\
\hline $\begin{array}{c}\text { Series A } \\
\text { Series D }\end{array}$ & $\mathrm{C} 20 / 25$ & 20.11 & 2.22 & 29.997 \\
\hline Series B & $\mathrm{C} 25 / 30$ & 26.52 & 2.67 & 31.904 \\
\hline $\mathrm{C} 1-\mathrm{a}, \mathrm{C} 1-\mathrm{b}$ & $\mathrm{C} 20 / 25$ & 21.23 & 2.30 & 30.351 \\
\hline $\mathrm{C} 2-\mathrm{a}, \mathrm{C} 2-\mathrm{b}$ & $\mathrm{C} 25 / 30$ & 26.28 & 2.65 & 31.837 \\
\hline $\mathrm{C} 3-\mathrm{a}, \mathrm{C} 3-\mathrm{b}$ & $\mathrm{C} 30 / 37$ & 31.47 & 2.99 & 33.213 \\
\hline
\end{tabular}

The properties of the other materials used in this test program such as steel of I-shape shear connectors, and steel of reinforcing bars, were also determined by tension tests. Three coupon samples were cut from the web of I-shape connectors and from the reinforcing bars. The specimens' size and the tensile test procedure have been performed according to the procedure proposed by ASTM-E8-69 [23]. The results of the tension tests are summarized in Table 3. The short beam of HEB160 profile was made from S355 steel grade of nominal tensile yield strength equal to $355 \mathrm{MPa}$. No tests have been performed on this element.

Table 3. Mechanical Properties of Steel Materials

\begin{tabular}{|c|c|c|c|c|c|}
\hline Specimens & Profile & Steel grade & $\begin{array}{c}\text { Average Yield } \\
\text { Strength, } f_{y}(\mathrm{MPa})\end{array}$ & $\begin{array}{c}\text { Average ultimate } \\
\text { Strength, } f_{u}(\mathrm{MPa})\end{array}$ & $\begin{array}{c}\text { Average } \\
\text { Elongation (\%) }\end{array}$ \\
\hline \multirow{2}{*}{$\begin{array}{c}\text { Steel of } \\
\text { I-shape } \\
\text { shear } \\
\text { connectors }\end{array}$} & IPE80 & S235 & 233 & 344 & 21 \\
\cline { 2 - 6 } & IPE100 & S235 & 241 & 356 & 27 \\
\hline $\begin{array}{c}\text { Reinforcing } \\
\text { bars }\end{array}$ & $\varnothing 8$ & $\mathrm{~S} 235$ & 237 & 350 & 24 \\
\hline
\end{tabular}

\subsection{Test Setup and Instrumentation}

The push-out specimens were tested under monotonic loading using a hydraulic testing machine of $600 \mathrm{kN}$ capacity. A $30 \mathrm{~mm}$ thick steel plate was used as a base plate for the specimens, and at the top end of the specimens, a $12 \mathrm{~mm}$ thick steel plate was placed on the steel section to distribute the applied loads. Prior to initializing the test, the specimens were preloaded several times to remove any lack of fit in the test set up. The preload force was then released, and equilibrium was established in the system. Initially, the load was applied in increments of $10 \mathrm{kN}$, when the load-slip curve started to deviate from a straight line, the load increment was reduced to $5 \mathrm{kN}$ until the maximum load. The loading was continued until failure occurred. During each load increment, the slip between the steel beam and the concrete slab and the separation of the concrete slabs from the steel flanges were measured by means of four $20 \mathrm{~mm}$ dial gauges located at the level of I-shape shear connectors. Each specimen took about 45 minutes till it completely failed. Figure 5 shows a typical test setup used for the push-out specimens. 


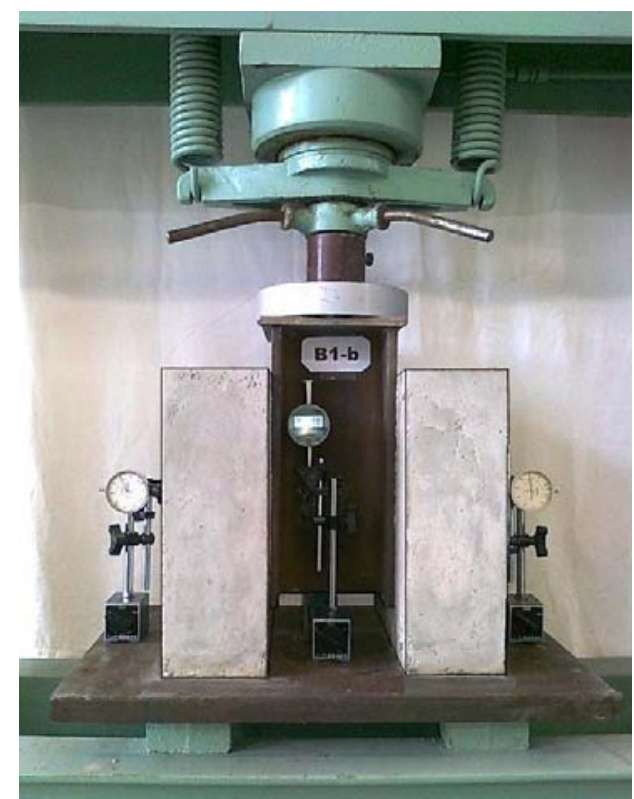

Figure 5. Test Setup and Instrumentation

\section{TEST RESULTS}

The results of the push-out tests are summarized in Table 4. The values of the load capacity and the ductility of the I-shape connector were evaluated in accordance with the specifications of Eurocode 4 [9] : The ultimate load capacity of a connector $P_{u}$ was obtained by dividing the failure load of the specimen by the number of connectors, the characteristic load $P_{R k}$ was taken as the least failure load divided by the number of connectors and reduced by $10 \%$, the slip capacity $S_{u}$ was considered as the maximum slip correspondent to the characteristic load $P_{R k}$ and the characteristic slip $S_{u k}$ was taken as $90 \%$ of the slip capacity i.e. $0.9 S_{u}$.

Table 4. Results of Push-out Tests

\begin{tabular}{|c|c|c|c|c|c|c|c|}
\hline \multirow{2}{*}{ Series } & \multirow{2}{*}{ Specimen } & \multicolumn{3}{|c|}{$\begin{array}{l}\text { Load capacity per connector } \\
(\mathrm{KN})\end{array}$} & \multicolumn{2}{|c|}{$\begin{array}{l}\text { Slip capacity } \\
(\mathrm{mm})\end{array}$} & \multirow[t]{2}{*}{ Mode of failure } \\
\hline & & $P_{\text {test }}$ & $P_{u}$ (avg.) & $P_{R k}$ & $S_{u}$ & $S_{u k}$ & \\
\hline \multirow{6}{*}{ A } & A1-a & 70.00 & \multirow{2}{*}{70.00} & \multirow{2}{*}{63.00} & \multirow{2}{*}{7.5} & \multirow{2}{*}{6.8} & \multirow{2}{*}{$\begin{array}{l}\text { Cracking + } \\
\text { crushing } \\
\text { of concrete }\end{array}$} \\
\hline & A1-b & 70.00 & & & & & \\
\hline & A2-a & 80.00 & \multirow{2}{*}{78.75} & \multirow{2}{*}{69.75} & \multirow{2}{*}{8.2} & \multirow{2}{*}{7.4} & \multirow{2}{*}{$\begin{array}{c}\text { Cracking + } \\
\text { crushing } \\
\text { of concrete }\end{array}$} \\
\hline & A2-b & 77.50 & & & & & \\
\hline & A3-a & 82.50 & \multirow{2}{*}{83.75} & \multirow{2}{*}{74.25} & \multirow{2}{*}{8.8} & \multirow{2}{*}{7.9} & \multirow{2}{*}{$\begin{array}{c}\text { Cracking + } \\
\text { crushing } \\
\text { of concrete }\end{array}$} \\
\hline & A3-b & 85.00 & & & & & \\
\hline \multirow{6}{*}{ B } & B1-a & 52.50 & \multirow{2}{*}{51.25} & \multirow{2}{*}{45.00} & \multirow{2}{*}{4.9} & \multirow{2}{*}{4.4} & \multirow{2}{*}{$\begin{array}{l}\text { Shearing } \\
\text { of connector }\end{array}$} \\
\hline & B1-b & 50.00 & & & & & \\
\hline & B2-a & 80.00 & \multirow{2}{*}{80.00} & \multirow{2}{*}{72.00} & \multirow{2}{*}{7.3} & \multirow{2}{*}{6.6} & \multirow{2}{*}{$\begin{array}{c}\text { Cracking + } \\
\text { crushing } \\
\text { of concrete }\end{array}$} \\
\hline & B2-b & 80.00 & & & & & \\
\hline & B3-a & 107.50 & \multirow{2}{*}{108.75} & \multirow{2}{*}{96.75} & \multirow{2}{*}{9.7} & \multirow{2}{*}{8.7} & \multirow{2}{*}{$\begin{array}{l}\text { Cracking + } \\
\text { crushing } \\
\text { of concrete }\end{array}$} \\
\hline & B3-b & 110.00 & & & & & \\
\hline
\end{tabular}




\begin{tabular}{|c|c|c|c|c|c|c|c|}
\hline \multirow{6}{*}{$\mathrm{C}$} & $\mathrm{C} 1-\mathrm{a}$ & 70.00 & \multirow{2}{*}{71.25} & \multirow{2}{*}{63.00} & \multirow{2}{*}{6.9} & \multirow{2}{*}{6.2} & \multirow{2}{*}{$\begin{array}{c}\text { Cracking }+ \\
\text { crushing } \\
\text { of concrete }\end{array}$} \\
\hline & $\mathrm{C} 1-\mathrm{b}$ & 72.50 & & & & & \\
\hline & $\mathrm{C} 2-\mathrm{a}$ & 80.00 & \multirow{2}{*}{80.00} & \multirow{2}{*}{72.00} & \multirow{2}{*}{7.8} & \multirow{2}{*}{7.0} & \multirow{2}{*}{$\begin{array}{c}\text { Cracking }+ \\
\text { crushing } \\
\text { of concrete }\end{array}$} \\
\hline & $\mathrm{C} 2-\mathrm{b}$ & 80.00 & & & & & \\
\hline & C3-a & 82.50 & \multirow{2}{*}{82.50} & \multirow{2}{*}{74.25} & \multirow{2}{*}{5.7} & \multirow{2}{*}{5.1} & \multirow{2}{*}{$\begin{array}{l}\text { Shearing } \\
\text { of connector }\end{array}$} \\
\hline & C3-b & 82.50 & & & & & \\
\hline \multirow{6}{*}{ D } & D1-a & 67.50 & \multirow[b]{2}{*}{68.75} & \multirow[b]{2}{*}{60.75} & \multirow[b]{2}{*}{6.8} & \multirow[b]{2}{*}{6.1} & \multirow{2}{*}{$\begin{array}{c}\text { Cracking + } \\
\text { crushing } \\
\text { of concrete }\end{array}$} \\
\hline & D1-b & 70.00 & & & & & \\
\hline & D2-a & 72.50 & \multirow[b]{2}{*}{71.25} & \multirow[b]{2}{*}{63.00} & \multirow[b]{2}{*}{8.2} & \multirow[b]{2}{*}{7.4} & \multirow{2}{*}{$\begin{array}{c}\text { Cracking }+ \\
\text { crushing } \\
\text { of concrete }\end{array}$} \\
\hline & D2-b & 70.00 & & & & & \\
\hline & D3-a & 75.00 & \multirow{2}{*}{73.75} & \multirow{2}{*}{65.25} & \multirow{2}{*}{8.4} & \multirow{2}{*}{7.6} & \multirow{2}{*}{$\begin{array}{c}\text { Cracking + } \\
\text { crushing } \\
\text { of concrete }\end{array}$} \\
\hline & D3-b & 72.50 & & & & & \\
\hline
\end{tabular}

\subsection{Failure Modes}

The failure modes observed from the push-out tests can be generally classified into two types, as presented in Table 4. The first mode of failure is the shearing of connector. The characteristic feature of this failure mode was the yielding and then shearing of the web near the welded flange fillet. Figure 6(a) shows the shearing of the I-shape connector with a remarkable cracking of concrete. The second mode of failure is the cracking and crushing of concrete slab in front of the connector as illustrated in Figure 6(b). It was noticed that the shearing of connector was occurred, especially in the specimens with higher strength concrete and/or with connectors of smaller length. However, in specimens made using low and moderate strength concrete, the failure was caused by cracking and crushing of the concrete slab.

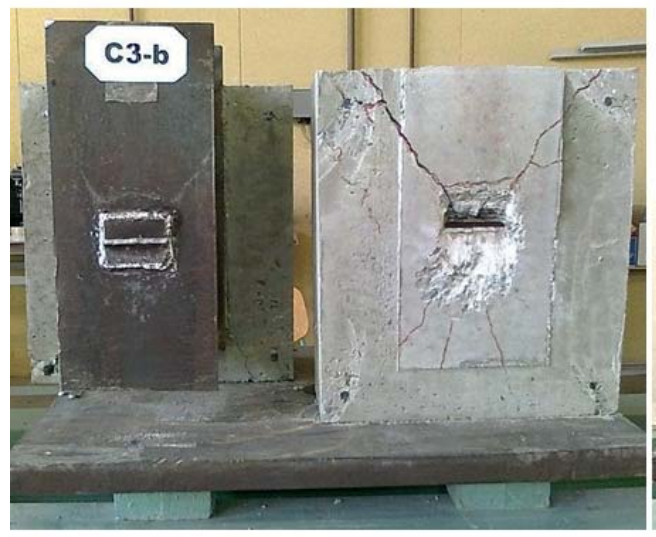

(a) Failure by shearing of connector web

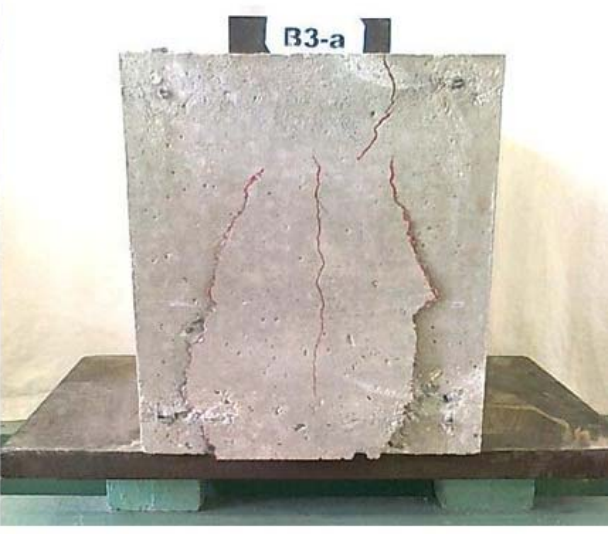

(b) Failure by cracking and crushing of concrete

Figure 6. Modes of Failure

\subsection{Load-slip Behaviour}

The load-slip curves of two specimens representing the two types of failure shown above are presented in Figure 7. Slip increased with increasing load until the specimen reached the ultimate load, and afterwards the load decreased systematically until failure. For the specimen C3-b, the 
shearing of I-shape connector was identified by a characteristic sound and load drop, and separation occurred on one side only. For the specimen B3-a, it appears that even after the cracking and crushing of concrete in front of the I-shape connector, the friction between the cracked concrete surfaces continued to provide shear resistance at large slips.

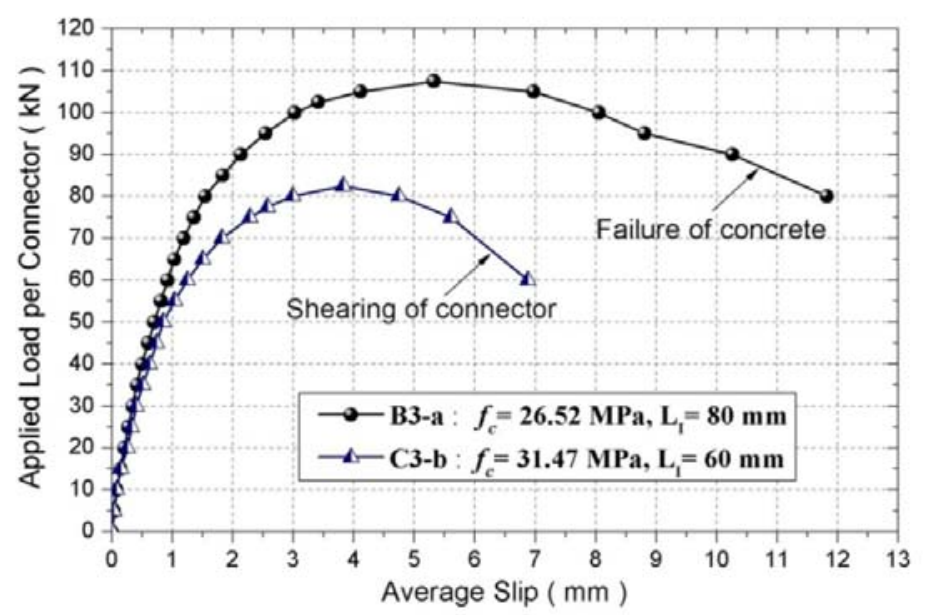

Figure 7. Typical Load-slip Curves for Specimens C3-b and B3-a

- According to Eurocode 4 [9], a connector may be taken as ductile if the characteristic slip $S_{u k}$ is at least $6 \mathrm{~mm}$. As indicated in Table 4, for the specimens that failed by cracking and crushing of concrete, the I-shape connectors are sufficiently ductile since they present a characteristic slip $S_{u k}$ greater than $6 \mathrm{~mm}$. While, for the specimens failed by shearing of connector, the characteristic slip $S_{u k}$ is slightly lower than $6 \mathrm{~mm}$ and the load-slip behaviour is less ductile. It worth noting that the push-tests were performed with load control due to some limitations of the testing machine at the time. It is possible that the values measured for slip are smaller than those that would be attained with displacement control.

- Concerning the separation of the concrete slabs, the uplift values obtained from the push-out tests with I-shape connectors, were found to be small and thus were considered to have minimal influence on the behaviour of these connectors.

\section{PARAMETRIC STUDY}

\subsection{Effect of the Height of I-shape Connector}

The load-slip curves for three pair specimens A1, A2, and A3 are shown in Figure 8. These specimens were similar in every respect except that the height of I-shape connector in specimens $\mathrm{A} 1, \mathrm{~A} 2$, and $\mathrm{A} 3$ was 80,100 , and $120 \mathrm{~mm}$, respectively. The length of I-shape connectors was 60 $\mathrm{mm}$. The compressive strength of concrete used in all three pair specimens was 20.11 MPa.

As the load-slip curves indicate, the ultimate load capacity of I-shape connector increased slightly with the increase in the height of connector. On average, the ultimate load increased by about $10 \%$ when the connector height was increased from $80 \mathrm{~mm}$ to $100 \mathrm{~mm}$. There was a further increase of $6 \%$ when the connector height was increased from $100 \mathrm{~mm}$ to $120 \mathrm{~mm}$. All three pair specimens failed due to Cracking and crushing of concrete. Since the height of I-shape connector has a small influence when failure is concrete related. However, the specimen with a higher connector showed a slightly more ductile behaviour. 


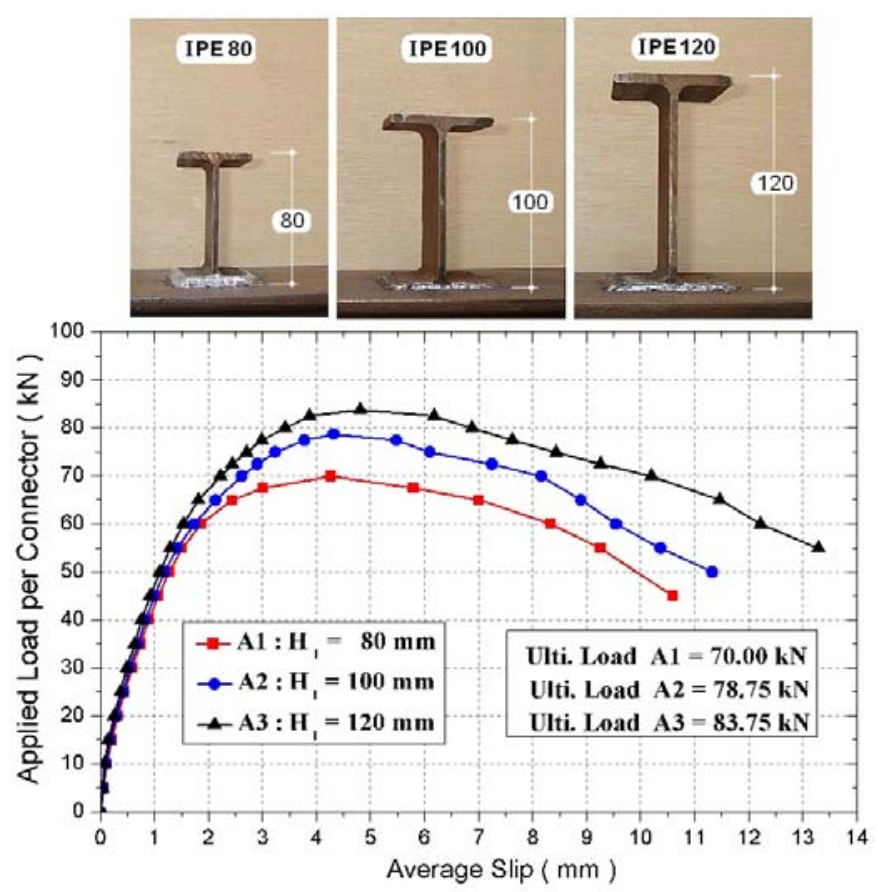

Figure 8. Effect of the Height of I-shape Connector

\subsection{Effect of the Length of I-shape Connector}

The load-slip curves for three pair of specimens B1, B2, and B3 are shown in Figure 9. These specimens were similar in every respect except that the length of I-shape connector in specimens $\mathrm{B} 1, \mathrm{~B} 2$, and B3 was 40,60 , and $80 \mathrm{~mm}$, respectively. The height of the connector used in these specimens was $80 \mathrm{~mm}$. The compressive strength of the concrete was $26.52 \mathrm{MPa}$. As the load-slip curves indicate, the ultimate load capacity is influenced significantly by the increase in connector length. On average, increasing the length of I-shape connector from $40 \mathrm{~mm}$ to $60 \mathrm{~mm}(50 \%)$ led to an increase in the ultimate load capacity of approximately $56 \%$, as well as a further increase of connector length from $60 \mathrm{~mm}$ to $80 \mathrm{~mm}(33 \%)$ led to an increase in the ultimate load capacity of approximately $27 \%$.

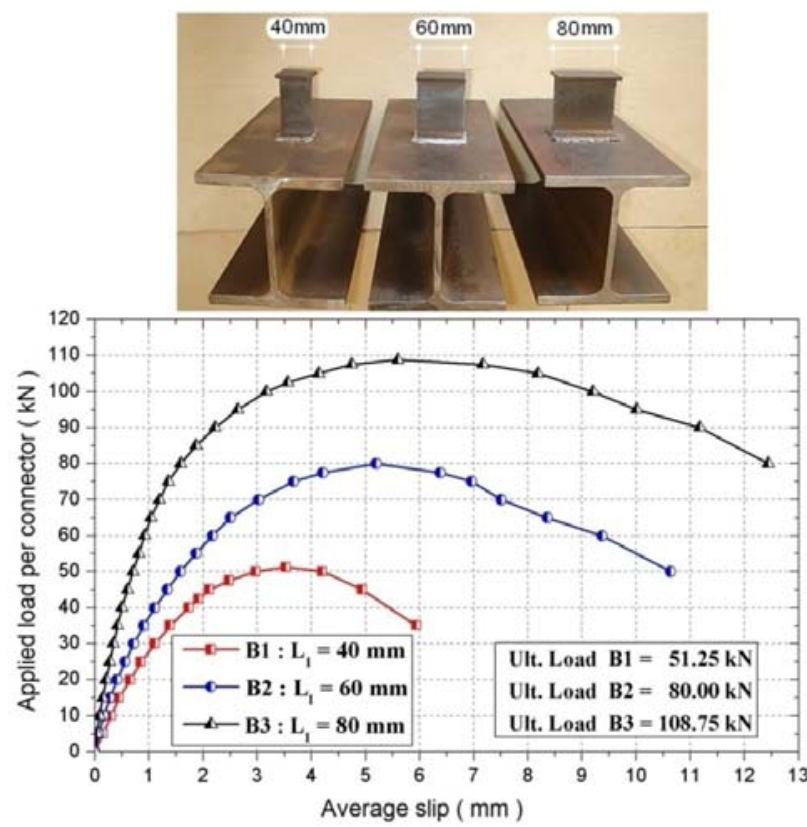

Figure 9. Effect of the Length of I-shape Connector 


\subsection{Effect of Concrete Strength}

Figure 10 presents the load-slip curves for three pair specimens $\mathrm{C} 1, \mathrm{C} 2$ and $\mathrm{C} 3$ which were identical except that the compressive strengths of concrete were $21.23,26.28$ and $31.47 \mathrm{MPa}$, respectively. As indicated in Table 4, it appears that the concrete strength governed the mode of failure. Shearing of connector was observed in the pair specimens C3 with the highest strength concrete while, in the two pair specimens $\mathrm{C} 1$ and $\mathrm{C} 2$ with lower and moderate strength concrete, respectively, failure was occurred by cracking and crushing of concrete. For an increase in the compressive strength of concrete from 21.23 to $26.28 \mathrm{MPa}(23.79 \%)$ the average increase in the ultimate load capacity of I-shape connector was approximately $12.25 \%$. However, when the concrete strength was further increased from 26.28 to $31.47 \mathrm{MPa}(19.75 \%)$, the ultimate load capacity of I-shape connector increased by only $3.13 \%$. This was expected since the failure mode at higher concrete strength was due to shearing of connector. In this case, the ultimate load capacity of I-shape connector is indirectly influenced by concrete strength.

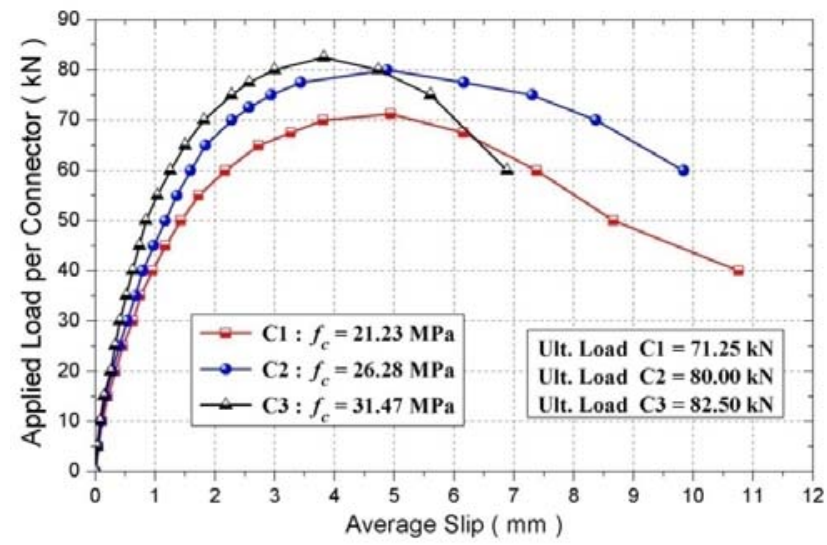

Figure 10. Effect of Concrete Strength for Specimens C1, C2 and C3

\subsection{Effect of transverse reinforcement}

The load-slip curves for three pair specimens D1, D2, and D3 are shown in Figure 11. These specimens were similar in every respect except that the number of transverse reinforcing bars in each concrete slab of specimens D1, D2, and D3 was 4Ø8, 6Ø8, and 8Ø8, respectively. The compressive strength of concrete used in all three pair specimens was $20.11 \mathrm{MPa}$. As the load-slip curves indicate, the ultimate load capacity was not significantly influenced by the increase in the number of transverse reinforcing bars. On average, increasing the number of transverse reinforcing bars from $4 \varnothing 8$ to $6 \varnothing 8$ led to an increase in the ultimate load capacity of approximately $5 \%$, while a further increasing of transverse reinforcing bars from $6 \varnothing 8$ to $8 \varnothing 8$ led to an increase in the ultimate load capacity of only approximately $2 \%$. However, the specimens with $6 \varnothing 8$ and $8 \varnothing 8$ exhibited a more ductile behaviour (i.e., larger maximum slip values) than the specimens with $4 \varnothing 8$. The reason for this difference in behaviour can be attributed to the presence of transverse reinforcing bars which limit the cracking of the concrete around the connector at the ultimate loads. 


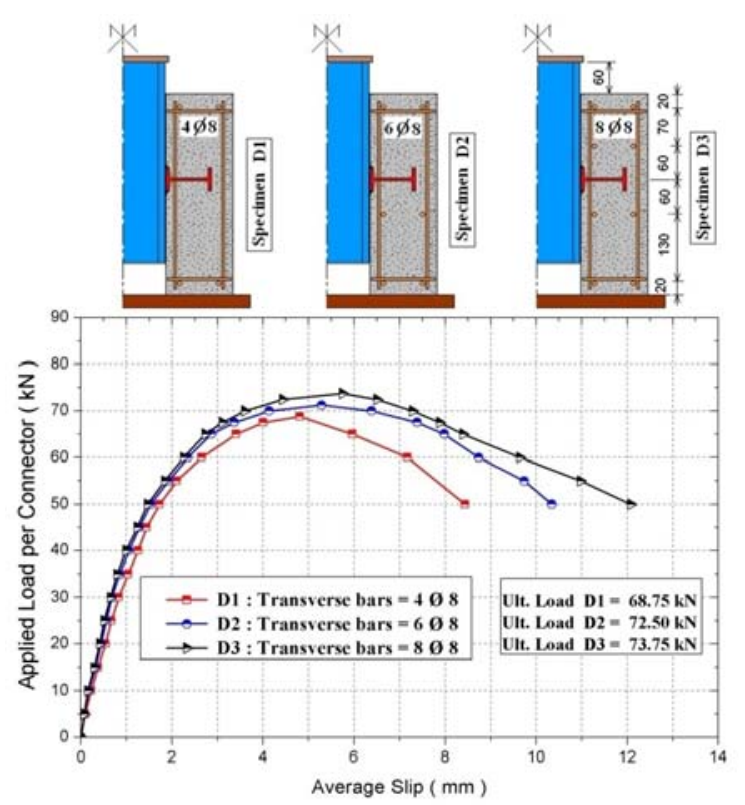

Figure 11. Effect of Transverse Reinforcement for Specimens D1, D2 and D3

\section{FINITE ELEMENT ANALYSIS}

During the preparation of the push-out specimens, we encountered difficulties in the installation of the strain gauges on the level of each I-shape connector. Therefore, to observe its local deformation, the finite element analysis serves better than that of the experimental investigation. Nevertheless, due to complexity of three-dimensional models (meshing difficulties, memory requirements, numerical convergence problems and result interpretation difficulties), a two-dimensional model was then chosen for simplicity.

Two-dimensional models with plane stress elements were used by many authors. Kim et al. [24] were one of the first researchers to employ a two-dimensional plane stress elements using LUSAS software to study the behaviour of through-deck welded shear connectors in push-out tests. The steel beam, concrete slab and stud were modelled by quadrilateral and triangular plane stress elements and the profiled steel sheeting by bar elements. Wang [25] proposed a two-dimensional model using ABAQUS software to investigate the behaviour of stud shear connectors with profiled steel sheeting in push-out tests. Quadrilateral plane stress elements were used to model the concrete slab, the steel beam and the profiled steel sheeting. Shear connectors were modelled by horizontal and vertical springs along the steel-concrete interface, and non-linear load-slippage curves representing realistic deformation characteristics were readily incorporated. Recently, Guezouli and Lachal [26] developed a new two-dimensional model to study the effect of steel-concrete contact and friction on the behaviour of stud shear connectors in push-out tests. It has been observed that the previous two-dimensional models with plane stress elements are able to predict satisfactorily the behaviour of the shear connectors both in terms of strength and ductility without any difficulty.

\subsection{Two-dimensional finite element model}

The push-out specimen shown in Figure 3 was modelled by a two-dimensional finite element model using ANSYS software [8]. Because of symmetry, only half of the specimen with one I-shape shear connector was built as shown in Figure 12. 


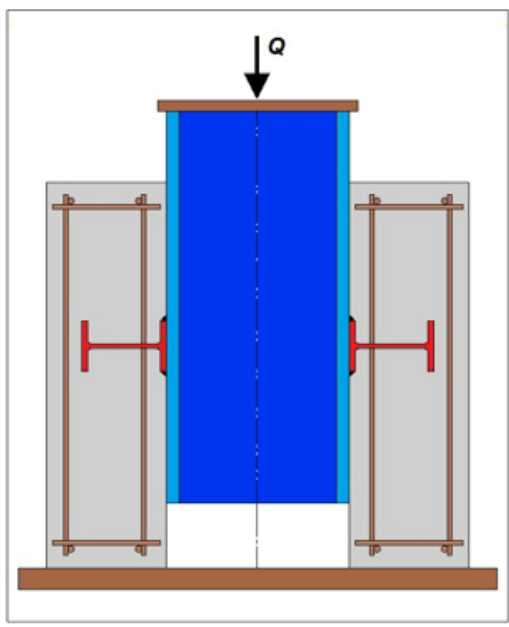

(a) Geometry of the push-out specimen

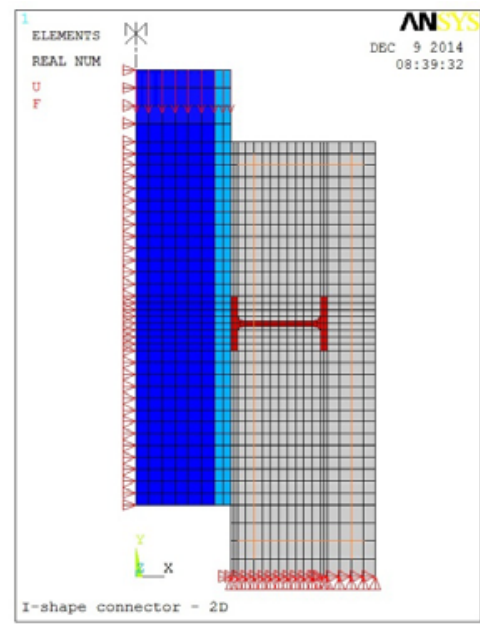

(b) Two-dimensionnel finite element model

Figure 12. Finite element modelling of push-out specimen with I-shape connector

\subsubsection{Finite element types}

The concrete slab, the steel beam and the I-shape connector were modelled using quadrilateral plane stress elements PLANE42, which have four nodes with two displacement degrees of freedom per node. The thicknesses of the plane stress elements were assigned to be equal to the effective width of the concrete slab as well as flange width and web thickness of the steel beam and the section of I-shape connector as appropriate. The reinforcing bars were modelled in a discrete manner using the two-dimensional spar element LINK1, which have two nodes with two displacement degrees of freedom per node. In this study, full bond action was assumed between the reinforcing bars and the concrete slab. Therefore, the nodes of LINK1 elements are attached to coincident nodes of PLANE42 elements of the concrete slab, so the two materials share the same nodes. The contacts along the steel-concrete interfaces between the I-shape connector and surrounding concrete and also between the flange of steel beam and concrete slab were modelled using a contact element CONTA171 associated with a target element TARGE169. These elements are able to simulate the existence of pressure between the elements when there is contact, and separation between the same ones when there is not. The contact pairs still allow the consideration of the friction between the parts. Hence, from the literature reviews, the friction coefficient developed at the interface (connector - surrounding concrete) was taken equal to 0.6 while at the interface (flange of steel beam - concrete slab) was taken equal to 0.01 because, in the push-out tests, the friction was eliminated by oiling of the steel beam flanges before the casting of concrete slabs.

\subsubsection{Material modelling of steel and concrete}

The material properties obtained from the tests were used in the finite element analyses. On one hand, the steel of I-shape connector, steel of reinforcing bars and steel beam were modelled as an isotropic elasto-plastic material in both tension and compression taking into account hardening effects. On the other hand, the behaviour of concrete was simulated by a simplified material model having different properties in tension and compression. In compression, the concrete was modelled by a multi-linear isotropic hardening relationship, which uses the von Mises yield criterion. In tension, the behaviour is linear up to the tensile strength of concrete. After this point, the softening branch remains horizontal to avoid numerical problems due to fact that the material nonlinearity in ANSYS cannot handle a negative gradient in the last stage of stress-strain curve. 


\subsubsection{Mesh and boundary conditions}

After the election of the suitable finite elements, the discretization of each part constituting the model was made by applying a coarse mesh as an overall size to reduce the time of analysis. The fine mesh was applied at the area of the I-shape connector in order to obtain more accurate results. Figure 12(b) shows the mesh and the boundary conditions adopted for the two-dimensional finite element model:

- All nodes along the middle of the steel beam web were restricted from moving in X direction due to symmetry.

- All nodes at the base of concrete slab were restricted from moving in $\mathrm{X}$ and $\mathrm{Y}$ directions to resist the compression load and to prevent the lateral spacing of the concrete slab at its base.

\subsubsection{Application of load and convergence criteria}

In this analysis, load control was applied. Loading was incrementally applied to the top line of the steel beam as shown in Figure 12(b). The slip was measured at the level of the I-shape connector. Therefore, the load-slip curve can be plotted and the ultimate load capacity can be determined. The ANSYS software [8] used the Newton-Raphson equilibrium iterations to provide convergence at the end of each load increment within tolerance limits. In this study, convergence criteria were based on force and displacement, and the convergence tolerance limits were initially selected by the ANSYS software [8]. The convergence limits for this analysis used the L2-norm (square root sum of the squares) of force tolerance equal to $0.1 \%$ and an L2-norm check on displacement with $5 \%$ tolerance.

\subsection{Calibration of the Finite Element Model}

In order to calibrate the finite element model, two push-out specimens (C3-b and B3-a) that were tested previously were simulated using the two-dimensional model described above. The dimensions of the push-out specimens and the test results were reported in the experimental part. Figure 13 presents a comparison between the (load-slip) curves recorded experimentally and those obtained numerically by the finite element method for the two specimens. There is good agreement between experimental and finite element results. Nevertheless, the numerical curves diverge from the experimental curves after the reaching of the ultimate load. This was due to the concrete material modelling used in the finite element analysis. For the specimen C3-b, the maximum load per one connector was recorded at $82.5 \mathrm{kN}$ compared with $85 \mathrm{kN}$ obtained from the finite element solution. For the specimen B3-a, the push-out test gave an ultimate load of $107.5 \mathrm{kN}$ compared with $115 \mathrm{kN}$ obtained from the finite element analysis.

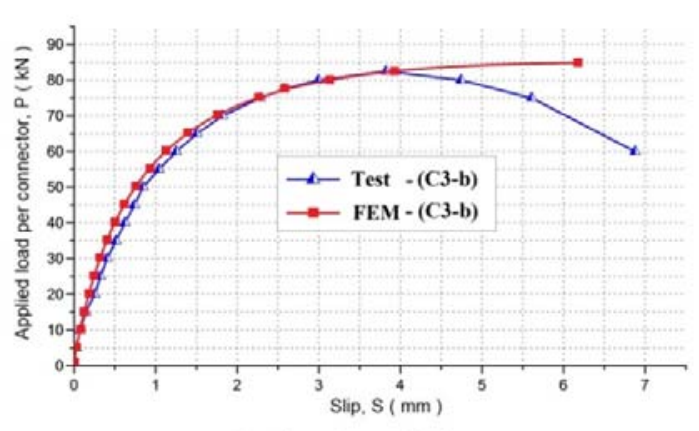

(a) Specimen C3-b

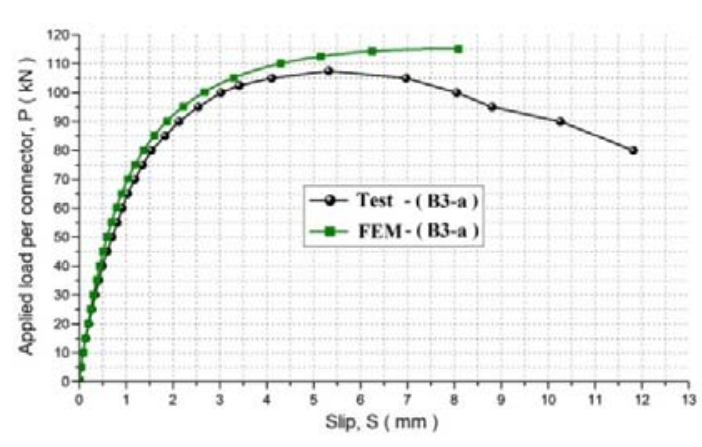

(b) Specimen B3-a

Figure 13. Load-slip Curves for Specimens C3-b and B3-a 
In the first specimen $\mathrm{C} 3-\mathrm{b}$, the failure of the shear connection was occurred by yielding and then shearing of the I-shape connector. This mode of failure was confirmed numerically by a concentration of the maximum stresses on the level of the web near the welded flange of I-shape connector as it can be seen in Figure 14(a). While, in the second specimen B3-a, the failure of shear connection was occurred by local crushing of the concrete around the I-shape connector. This mode of failure was also confirmed by the finite element analysis. As shown in Figure 14(b), a concentration of the maximum stresses was observed in the concrete at the frontal area of the connector.

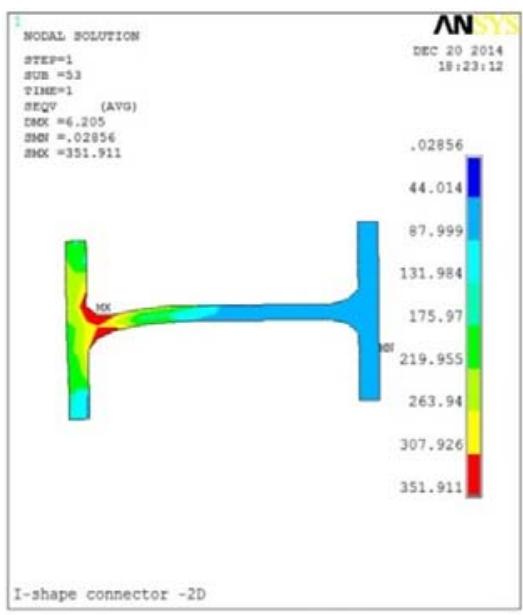

(a) Specimen C3-b

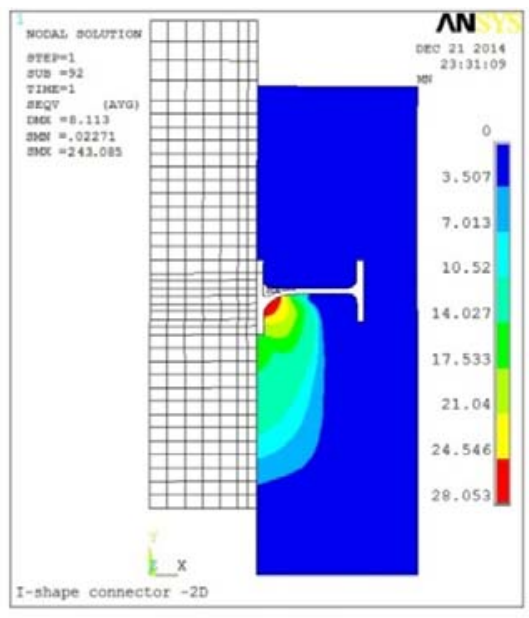

(b) Specimen B3-a

Figure 14. Stress Contour and Deformed Shape for Specimens C3-b and B3-a

The deformed shape of the connector after the failure of the specimen B3-a is compared with the finite element result. As it is shown in Figure 15, a separation of the concrete behind the connector was occurred in the push-out test. This separation was also noticed during the finite element analysis.
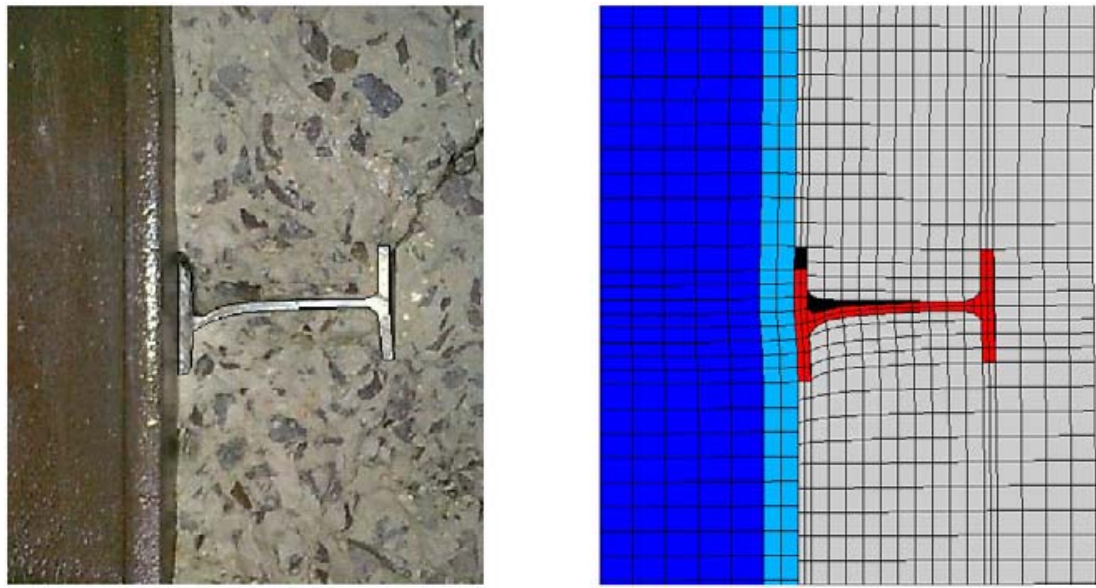

Figure 15. Typical deformed shape of the I-shape connector (specimen B3-a)

\subsection{Modelling of the Push-out Specimens with Channel Connector}

A simulation of the push-out specimens with channel shear connector of U-shape was conducted using the verified two-dimensional model in order to compare its behaviour with that of I-shape connector. Dimensions and mechanical properties of the two types of shear connectors are identical. Figure 16 shows the mesh and boundary conditions of the corresponding push-out specimens. 

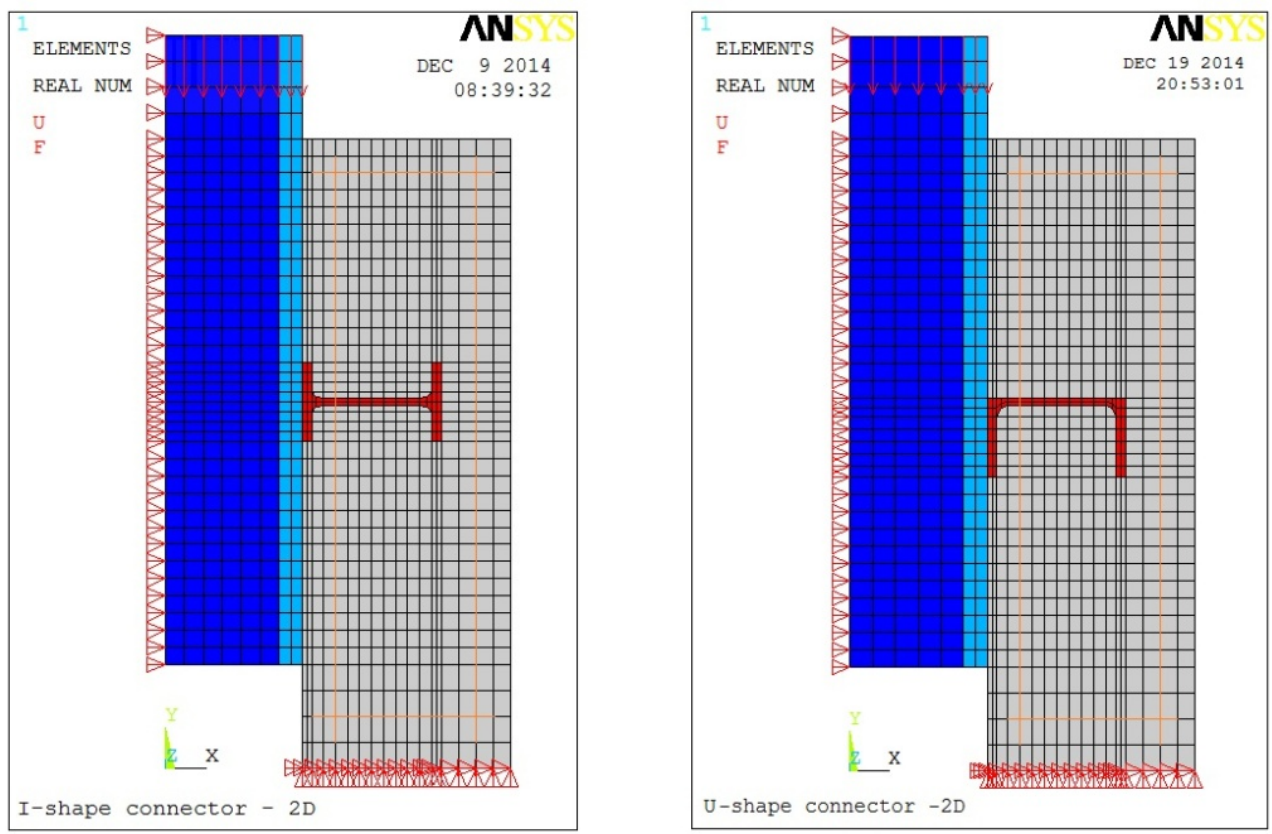

Figure 16. Mesh and Boundary Conditions for the Two Types of Shear Connectors

Figure 17 shows a comparison between the (load-slip) curves obtained from the finite element analysis for the two types of shear connectors. There is good agreement between the two curves for the two specimens C3-b and B3-a. However, the load-slip curve of channel connector appears more rigid and slightly higher than that of I-shape connector.

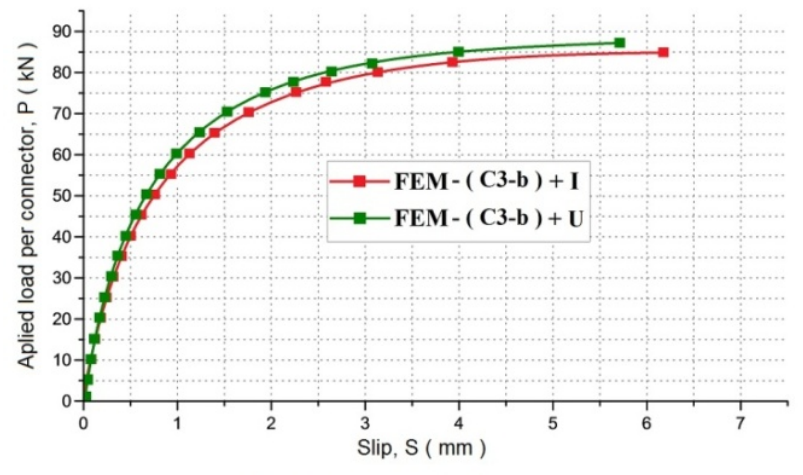

(a) Specimen C3-b

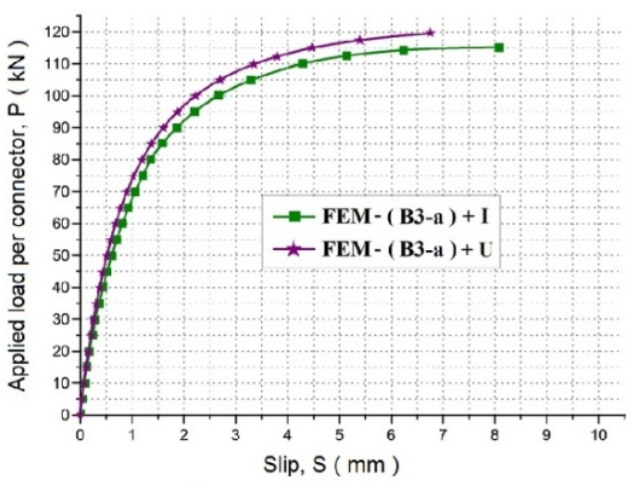

(b) Specimen B3-a

Figure 17. Comparison between the Load-slip Curves for the Two Types of Shear Connectors

As shown in Figure 18, the mode of failure by yielding and then shearing of the steel connector was confirmed numerically by a concentration of the maximum stresses at the junction of web and welded flange for the two types of shear connectors. 

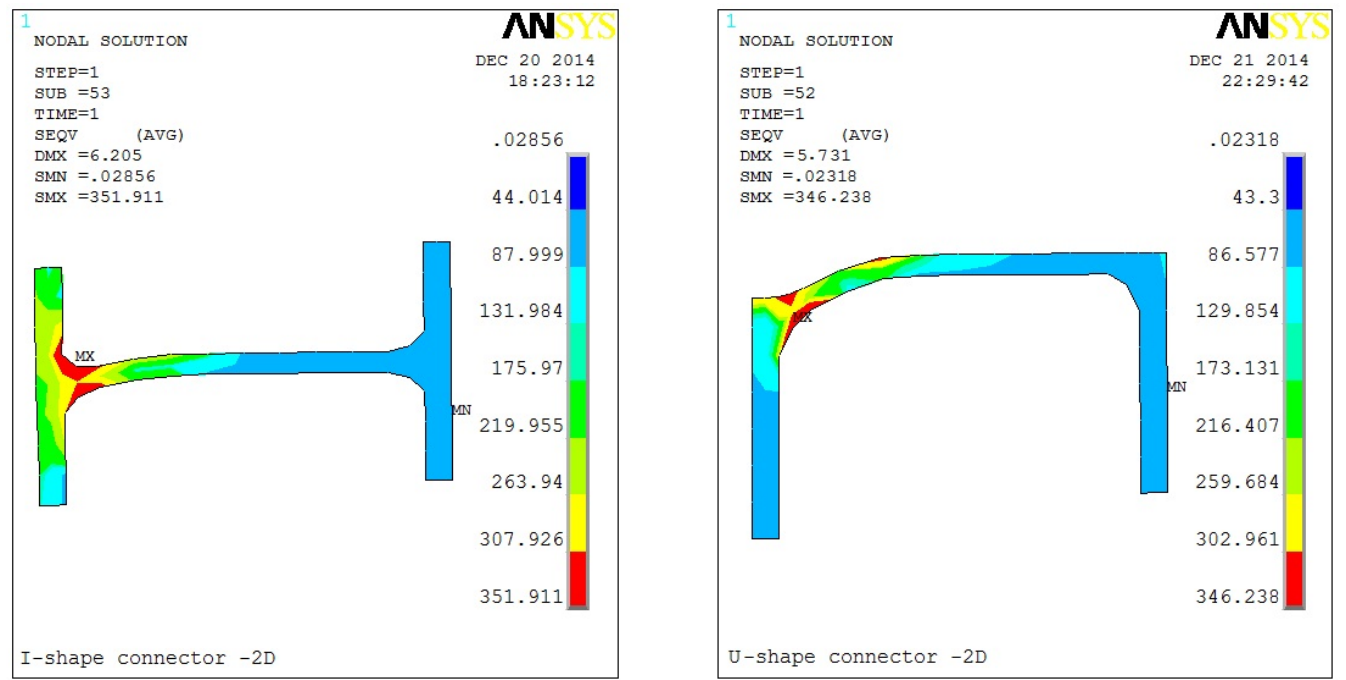

Figure 18. Stress Contour and Deformed Shape of the Two Types of Shear Connectors

The mode of failure by crushing of the concrete was also confirmed numerically for the two types of shear connectors. As shown in Figure 19, a concentration of the maximum stresses was observed in the concrete at the frontal area of the connector for the two types of shear connectors.
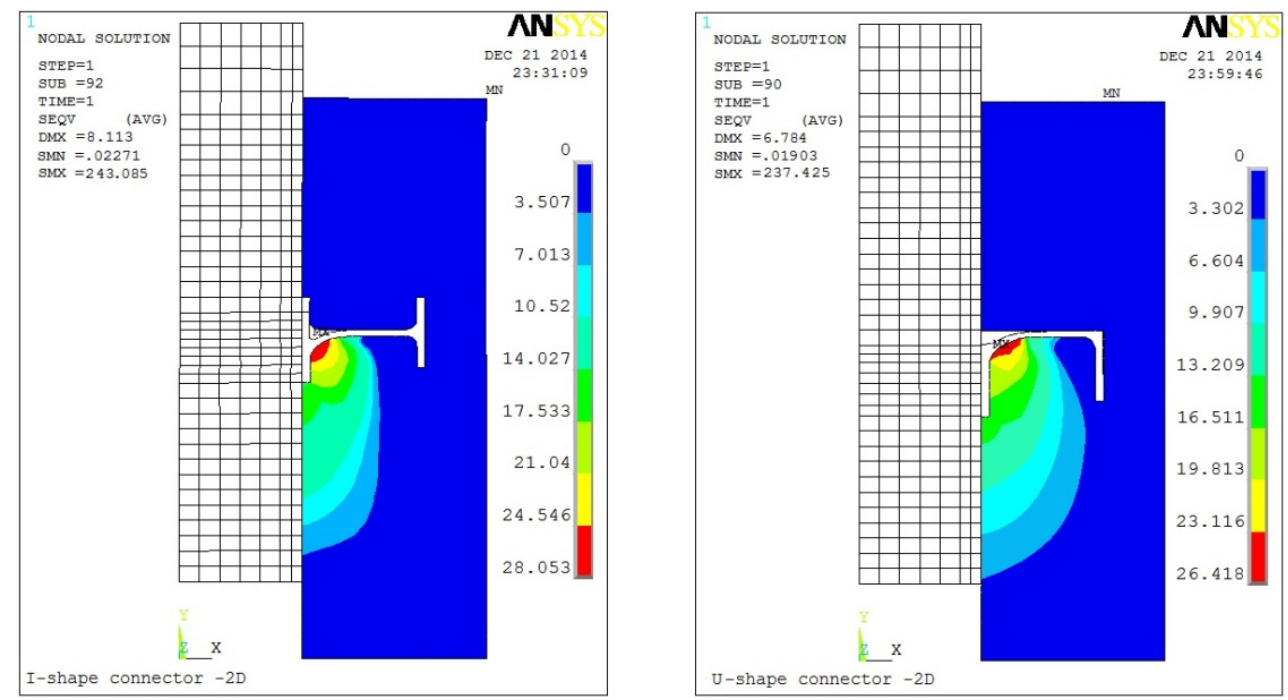

Figure 19. Stress Contour in the Concrete for the Two Types of Shear Connectors

\section{ESTIMATION OF THE ULTIMATE LOAD CAPACITY OF I-SHAPE CONNECTOR}

As mentioned above, the finite element analysis of the push-out tests on the two types of shear connectors confirms the similarity of their behaviour. Therefore, the ultimate load capacity of the I-shape connector can be estimated with the same formulas that have been developed for the channel connector.

From the literature, Slutter and Driscoll [27] suggested an empirical equation to predict the ultimate load capacity of a channel shear connector embedded in a solid concrete slab. This expression was later modified to be able to use it with light-weight concrete, and presented in the American Institute of Steel Construction specification [28] in the following form: 
$P_{u}=0.3\left(t_{f}+0.5 t_{w}\right) L_{c} \sqrt{f_{c k} E_{c m}}$

where $P_{u}$ is the ultimate load capacity of a channel shear connector $(\mathrm{N}), t_{f}$ is the flange thickness of channel shear connector $(\mathrm{mm}), t_{w}$ is the web thickness of channel shear connector $(\mathrm{mm}), L_{c}$ is length of channel shear connector $(\mathrm{mm}), f_{c k}$ is the compressive strength of concrete (MPa), and $E_{c m}$ is the modulus of elasticity of concrete (MPa).

The current Canadian standard CAN/CSA-S16-01 [29] also suggests a similar equation to predict the ultimate load capacity of channel shear connectors:

$$
P_{u}=36.5\left(t_{f}+0.5 t_{w}\right) L_{c} \sqrt{f_{c k}}
$$

Pashan and Hosain [30] concluded that the CSA equation is too conservative. By including channel height $H_{c}$ as a parameter, they developed the following empirical equation to evaluate the load capacity of channels having a height of $100 \mathrm{~mm}$ :

$$
P_{u}=\left(336 t_{w}^{2}+5.24 L_{c} H_{c}\right) \sqrt{f_{c k}}
$$

Considering the similarity of the behaviour between the two types of shear connectors, a comparison between the ultimate load values obtained from the push-out tests and those predicted by the above equations are listed in Table 5. It appears that the ultimate load capacity predicted by Eq. 2 is closer to the experimental results compared with the results obtained from Eqs. 1 and 3. The average arithmetic mean $(\mu)$ of the ratio of test to predicted values, the standard deviation $(\sigma)$, and the coefficient of variation $(v)$ for Eq. 2 are 1.003, 0.030, and 2.972\%, respectively. However, this equation was found to overestimate the ultimate load capacity when the mode of failure is shearing of connector. Therefore, another formula for ultimate load capacity of I-shape shear connector at this failure mode is necessary. Then, the final form of the adopted equation is:

$$
P_{u}=36.5\left(t_{f}+0.5 t_{w}\right) L_{I} \sqrt{f_{c k}} \leq A_{s c} f_{u}
$$

where $P_{u}$ is the predicted ultimate load of the I-shape connector $(\mathrm{N}) ; t_{f}$ is the flange thickness of the I-shape connector $(\mathrm{mm}) ; t_{w}$ is the web thickness of the I-shape connector $(\mathrm{mm}) ; L_{I}$ is the length of the I-shape connector $(\mathrm{mm}) ; f_{c k}$ is the compressive cylinder strength of concrete (MPa) ; $A_{s c}$ is the shear area of I-shape connector $\left(\mathrm{mm}^{2}\right), A_{s c}=t_{w} \cdot L_{I} ; f_{u}$ is the ultimate tensile strength of the I-shape connector steel.

The first equation refers to the concrete crushing failure, and the second corresponded to the

\begin{tabular}{|c|c|c|c|c|c|c|c|c|}
\hline \multirow{2}{*}{$\begin{array}{c}\text { Specimen } \\
\mathrm{N}^{\circ}\end{array}$} & \multicolumn{5}{|c|}{ Ultimate load per I-shape shear connector $(\mathrm{kN})$} & \multirow{2}{*}{$\frac{\text { Test }}{\text { Eq.(1) }}$} & \multirow{2}{*}{$\frac{\text { Test }}{\text { Eq.(2) }}$} & \multirow{2}{*}{$\frac{\text { Test }}{\text { Eq.(3) }}$} \\
\hline & Test & Avg. & Eq. (1) & Eq. (2) & Eq. (3) & & & \\
\hline Al-a & 70.00 & \multirow{2}{*}{70.00} & \multirow{2}{*}{97.40} & \multirow{2}{*}{69.73} & \multirow{2}{*}{134.55} & \multirow{2}{*}{0.72} & \multirow{2}{*}{1.00} & \multirow{2}{*}{0.52} \\
\hline A1-b & 70.00 & & & & & & & \\
\hline A2-a & 80.00 & \multirow{2}{*}{78.75} & \multirow{2}{*}{106.32} & \multirow{2}{*}{76.11} & \multirow{2}{*}{166.32} & \multirow{2}{*}{0.74} & \multirow{2}{*}{1.03} & \multirow{2}{*}{0.47} \\
\hline A2-b & 77.50 & & & & & & & \\
\hline A3-a & 82.50 & \multirow{2}{*}{83.75} & \multirow{2}{*}{116.61} & \multirow{2}{*}{83.48} & \multirow{2}{*}{198.36} & \multirow{2}{*}{0.72} & \multirow{2}{*}{1.00} & \multirow{2}{*}{0.42} \\
\hline A3-b & 85.00 & & & & & & & \\
\hline B1-a & 52.50 & \multirow{2}{*}{51.25} & \multirow{2}{*}{77.17} & \multirow{2}{*}{53.38} & \multirow{2}{*}{111.34} & \multirow{2}{*}{0.66} & \multirow{2}{*}{0.96} & \multirow{2}{*}{0.46} \\
\hline B1-b & 50.00 & & & & & & & \\
\hline
\end{tabular}
shearing of the connector. The lesser of the two values is used in the design.

Table 5. Comparison of Experimental and Predicted Values for Ultimate Load Capacity 


\begin{tabular}{|c|c|c|c|c|c|c|c|c|}
\hline B2-a & 80.00 & \multirow{2}{*}{80.00} & \multirow{2}{*}{115.75} & \multirow{2}{*}{80.07} & \multirow{2}{*}{154.51} & \multirow{2}{*}{0.69} & \multirow{2}{*}{1.00} & \multirow{2}{*}{0.52} \\
\hline B2-b & 80.00 & & & & & & & \\
\hline B3-a & 107.50 & \multirow{2}{*}{108.75} & \multirow{2}{*}{154.33} & \multirow{2}{*}{106.76} & \multirow{2}{*}{197.69} & \multirow{2}{*}{0.70} & \multirow{2}{*}{1.02} & \multirow{2}{*}{0.55} \\
\hline B3-b & 110.00 & & & & & & & \\
\hline $\mathrm{C} 1-\mathrm{a}$ & 70.00 & \multirow{2}{*}{71.25} & \multirow{2}{*}{100.73} & \multirow{2}{*}{71.64} & \multirow{2}{*}{138.25} & \multirow{2}{*}{0.71} & \multirow{2}{*}{0.99} & \multirow{2}{*}{0.52} \\
\hline C1-b & 72.50 & & & & & & & \\
\hline $\mathrm{C} 2-\mathrm{a}$ & 80.00 & \multirow{2}{*}{80.00} & \multirow{2}{*}{115.09} & \multirow{2}{*}{79.71} & \multirow{2}{*}{153.81} & \multirow{2}{*}{0.70} & \multirow{2}{*}{1.00} & \multirow{2}{*}{0.52} \\
\hline $\mathrm{C} 2-\mathrm{b}$ & 80.00 & & & & & & & \\
\hline C3-a & 82.50 & \multirow{2}{*}{82.50} & \multirow{2}{*}{128.94} & \multirow{2}{*}{87.23} & \multirow{2}{*}{168.32} & \multirow{2}{*}{0.64} & \multirow{2}{*}{0.95} & \multirow{2}{*}{0.49} \\
\hline C3-b & 82.50 & & & & & & & \\
\hline D1-a & 67.50 & 6875 & 9740 & 6973 & 13455 & 071 & 099 & 051 \\
\hline D1-b & 70.00 & 08.15 & 91.40 & & 134.55 & 0.11 & 0.99 & 0.51 \\
\hline D2-a & 72.50 & 7250 & 9740 & 69.73 & 134.55 & 0.74 & 1.04 & 0.54 \\
\hline D2-b & 72.50 & 12.00 & (19.40 & 09.13 & & & & \\
\hline D3-a & 75.00 & 7375 & 0740 & 6973 & 13455 & 076 & 106 & 055 \\
\hline D3-b & 72.50 & 13.15 & 91.40 & 69.15 & 134.50 & 0.10 & 1.06 & 0.55 \\
\hline & Aver & e arithr & tic mean & $(\mu)$ & & 0.708 & 1.003 & 0.506 \\
\hline & Stan & ard devi & & $(\sigma)$ & & 0.032 & 0.030 & 0.036 \\
\hline & Coef & cient of & riation & $(v)$ & & $4.548 \%$ & $2.972 \%$ & $7.130 \%$ \\
\hline
\end{tabular}

\section{CONCLUSION}

This paper presented the results of tests performed on 24 push-out specimens to investigate the feasibility of using I-shape pieces as shear connectors. Furthermore, a finite element modelling of the push-out tests was carried out using ANSYS software to investigate the stress distribution pattern in the area of the I-shape shear connector. Moreover, the finite element model was also used to simulate another type of shear connector, called channel connector in order to compare its behaviour with that of the I-shape shear connector. From this comparison, we suggested an equation for the prediction of the ultimate load capacity of the specific shear connector proposed in this research. From this study, the following conclusions are drawn concerning the failure modes, the ductility and the ultimate load capacity:

- The failure modes observed from the push-out tests can be generally classified into two types: Shearing of the connector and Crushing-cracking of the concrete slab. The shearing of the connector was occurred, especially in the specimens with connectors of lower steel grade and smaller length embedded in concrete slabs of higher strength. However, in specimens with I-shape connectors of higher steel grade and concrete slabs of low and moderate strength, failure was caused by cracking and crushing of the concrete surrounding the connector.

- For most push-out tests, the characteristic slip capacity was found greater than $6 \mathrm{~mm}$. Therefore, the I-shape shear connector can be considered as ductile, according to Eurocode 4.

- Concerning the separation of the concrete slabs, the uplift values obtained from the push-out tests, were found to be small and thus were considered to have minimal influence on the behaviour of I-shape shear connectors.

- The comparison between the I-shape connector and the channel connector by the finite element analysis confirms the similarity of their behaviour. Therefore, the Canadian code equation that has been adopted for the channel connectors is capable of predicting the ultimate load capacity of I-shape connectors with reasonable accuracy.

- Finally, the I-shape connectors can be effectively used in composite beams to transfer the longitudinal shear forces across the steel-concrete interface, but further experimental investigations are necessary to study their behaviour in simply supported and continuous composite beams. 


\section{ACKNOWLEDGEMENTS}

The authors would like to thank the Laboratory of Materials and Mechanics of Structures at the University of M'sila, Algeria, where the tests were conducted. The donation of steel beams by the company of BATICIC, Algeria, is gratefully acknowledged.

\section{REFERENCES}

[1] Kim, S.H., Choi, K.T., Park, S.J., Park, S.M. and Jung, C.Y., "Experimental Shear Resistance Evaluation of Y-type Perfobond Rib Shear Connector", J. Constr. Steel Res., 2013, Vol. 82, pp. 1-18.

[2] Yan, J., Liew, J.Y.R., Sohel, K.M.A. and Zhang, M.H., "Push-out Tests on J-hook Connectors in Steel-concrete-steel Sandwich Structure", Materials and Structures, RILEM, 2013, Vol. 47, No. 10, pp. 1693-1714.

[3] Pavlović, M., Marković, Z., Veljković, M. and Buđevac, D., "Bolted Shear Connectors vs. Headed Studs Behaviour in Push-out Tests", J. Construct. Steel Res., 2013, Vol. 88, pp. $134-149$.

[4] Xu, X., Liu, Y. and He, J., "Study on Mechanical Behavior of Rubber-sleeved Studs for Steel and Concrete Composite Structures", Construction and Building Materials, 2014, Vol. 53, pp. 533-546.

[5] Shariati, M., Sulong, N.H.R., Shariati, A. and Khanouki M.M.A., "Behavior of V-shaped Angle Shear Connectors: Experimental and Parametric Study", Materials and Structures, RILEM, First online: 10 December 2015, pp. 1-18.

[6] Shariati, M., Sulong, N.H.R., Suhatril, M., Shariati, A., Khanouki M.M.A. and Sinaei H., "Comparison of Behaviour between Channel and Angle Shear Connectors under Monotonic and Fully Reversed Cyclic Loading", Construction and Building Materials, 2013, Vol. 38, pp. 582 - 593.

[7] Mazoz, A., Benanane, A. and Titoum, M., "Push-out Tests on a New Shear Connector of I-shape”, Int. J. Steel Struct., 2013, Vol. 13, No. 3, pp. 519-528.

[8] Swanson Analysis Systems Inc., “ANSYS, Version 12.0 and User's Manual”, Canonsburg, Pennsylvania, 2009.

[9] EN 1994-1-1, Eurocode 4: "Design of Composite Steel and Concrete Structures - Part 1-1: General Rules and Rules for Buildings", Brussels, European Committee for Standardization, 2005.

[10] BS 5400, Steel, Concrete and Composite Bridges, Part-5: Code of Practice for Design of Composite Bridges, British Standard Institution, London, 1979.

[11] Malite, M., "Analysis of the Structural Behaviour of Steel-concrete Composite Beams Using Cold-formed Shapes", Ph.D. Thesis (text in Portuguese), University of Sao Paulo, Sao Carlos, 1993.

[12] Maleki, S. and Mahoutian, M., "Experimental and Analytical Study on Channel Shear Connectors in Fiber-reinforced Concrete", J. Construct. Steel Res., 2009, Vol. 65, pp. 1787-1793.

[13] Shariati, M., Sulong, N.H.R. and Arabnejad, M.M., "Experimental Assessment of Channel Shear Connectors under Monotonic and Fully Reversed Cyclic Loading in High Strength Concrete", Materials and Design, 2012, Vol. 34, pp. 325 - 331.

[14] Prakash, A., Anandavalli, N., Madheswaran, C.K. and Lakshmanan, N., "Modified Push-out Tests for Determining Shear Strength and Stiffness of HSS Stud Connector - Experimental Study", International Journal of Composite Materials, 2012, Vol. 2, No. 3, pp. 22-31.

[15] Han, Q., Wang, Y., Xu, J. and Xing, Y., "Static Behavior of Stud Shear Connectors in Elastic Concrete-steel Composite Beams”, J. Constr. Steel Res., 2015, Vol. 113, pp. 115-126. 
[16] Veldanda, M.R. and Hosain, M.U., "Behaviour of Perfobond Rib Shear Connectors: Push-out tests", Can. J. Civ. Eng., 1992, Vol. 19, pp. 1 - 10.

[17] Studnicka, J., Machacek, J., Krpata, A. and Svitakova, M., "Perforated Shear Connector for Composite Steel and Concrete Beams", Proceedings of the Conference Composite Construction in Steel and Concrete IV, Banff, Alberta, Canada, 2000, pp. 367 - 378.

[18] Medberry, S.B. and Shahrooz, B.M., "Perfobond Shear Connector for Composite Construction", AISC Engineering Journal, 2002, Vol. 1, pp. 2-12.

[19] Veríssimo, G.S., "Development of An Indented Steel Rib Shear Connector for Composite Steel-concrete Structures and Study of Its Structural Behaviour", PhD Thesis (Text in Portuguese), Belo Horizonte, Federal University of Minas Gerais, 2007.

[20] Vianna, J.C., Costa-Neves, L.F., Vellasco. P.C.G.S. and Andrade, S.A.L., "Experimental Assessment of Perfobond and T-perfobond Shear Connectors', Structural Response", J. Construct. Steel Res., 2009, Vol. 65, No. 2, pp. 408 - 421.

[21] Baran, E. and Topkaya, C., "An Experimental Study on Channel Type Shear Connectors", J. Constr. Steel Res., 2012, Vol. 74, pp. 108 - 117.

[22] EN 1992-1-1, Eurocode 2: "Design of Concrete Structures - Part 1-1: General Rules and Rules for Buildings", Brussels, European Committee for Standardization, 2005.

[23] American Society for Testing and Materials - ASTM: E8 -69, "Standard Methods of Tension Testing of Metallic Materials", Annual Book of Standards, Washington, 2008.

[24] Kim, B., Wright, H.D. and Cairns, R., "The Behaviour of Through-deck Welded Shear Connectors: An Experimental and Numerical Study”, J. Construct. Steel Res., 2001, Vol. 57, pp. $1359-1380$.

[25] Wang, A.J., "Advanced Finite Element Investigation into Structural Behaviour of Composite Beams”, Ph.D. Thesis, The Hong Kong Polytechnic University, 2007.

[26] Guezouli, S. and Lachal, A., "Numerical Analysis of Frictional Contact Effects in Push-out Tests", Engineering Structures, 2012, Vol. 40, pp. 39 - 50.

[27] Slutter, R.G. and Driscoll, G.C., "Flexural Strength of Steel-concrete Composite Beams", Journal of Structural Division, ASCE, 1965, Vol. 91(ST2), pp. 71 - 99.

[28] American Institute of Steel Construction, AISC-360-05: "Specification for Structural Steel Buildings", Chicago, 2005.

[29] Canadian Standards Association, CSA-S16-01: "Limit States Design of Steel Structures", Toronto, Ontario, Canada, 2001.

[30] Pashan, A. and Hosain M.U., "New Design Equations for Channel Shear Connectors in Composite Beams”, Can. J. Civil Eng., 2009, Vol. 36, pp. 1435 - 43. 